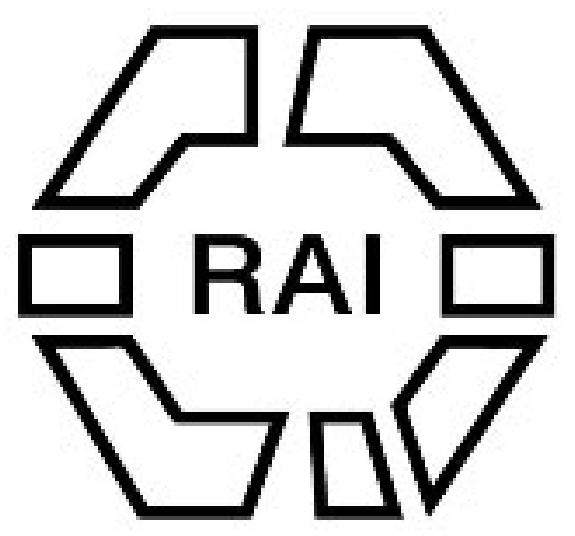

Notes on the Natives of Tanna

Author(s): W. Gray

Source: The Journal of the Anthropological Institute of Great Britain and Ireland, Vol. 28, No. $1 / 2$ (1899), pp. 127-132

Published by: Royal Anthropological Institute of Great Britain and Ireland

Stable URL: http://www.jstor.org/stable/2842937

Accessed: 15/06/2014 11:38

Your use of the JSTOR archive indicates your acceptance of the Terms \& Conditions of Use, available at http://www.jstor.org/page/info/about/policies/terms.jsp

JSTOR is a not-for-profit service that helps scholars, researchers, and students discover, use, and build upon a wide range of content in a trusted digital archive. We use information technology and tools to increase productivity and facilitate new forms of scholarship. For more information about JSTOR, please contact support@jstor.org. 


\section{NOTES ON THE NATIVES OF TANNA.}

By the Rev. W. Gray, Jamestown, S.A.

[WITH PLATE XI.]

In preparing the following notes I have taken as my guide the second edition of Notes and Queries on Anthropology. As it is three years since I left the Island of Tanna, I have not had the advantage of being on the spot where I could refer to the natives. I have, however, confined myself to matters within my knowledge, and trust the information I am able to give may be of some service to Antliropology.

The Colour and Character of the Skin.-The most common colours of skin are sooty biack and a red copper tint. A few of the natives are almost black, but none of them are coal black. There are likewise some who are of a brownish white and others of a rosy white (10 of Topinard's list).

In young people and persons not subject to excessive exposure the skin is velvety. In those who have a strain of Maori blood it has an oily look. I have never seen freckles.

The Hair.-I have not observed any really black hair. Dark brown is the most common colour, but chestnut brown is nearly as common. Fair blond hair comes next in frequency and is the colour coveted. These are all woolly in character. Red hair is only found where there is a taint of Maori blood, and it is wavy in character. The dark hairs are soft in childhood and get darker with age. The blonds have flaxen hair in childhood. Nothing is done to produce curliness or the reverse, but many persons use lime to bleach the hair. The hair grows uniformly over the scalp.

I have never seen an adult Tanna man without a beard. Some of them have an abundant growth of hair on the cheeks, chin, and lips, while others have the billy-goat beard and little hair on the cheeks. Fair-skinned people are covered with fine downy hair, while those with dark skins have strong long hair growing thickly all over the chest, spine, and sometimes on the back of the shoulders.

It is difficult to say when greyness sets in, probably not before the age of 45 to 50 years. Baldness is rare. It begins above the forehead and temples and extends backwards. The Tanna system of dressing the hair has the effect of thinning it. Baldness in women is very rare.

Characters of the Face.-Considerable variety in the form of the outline of the nose, as seen in profile, occurs. On the whole the face is flat, but sunken across the eyes and root of nose. In respect to actual shape considerable variety also exists; in persons of fair complexion the shield shape form predominates. 
The lips are always thick and everted, but to different degrees. The ears are small and fine.

Powers of endurance.-Tannese bear cold badly. They shiver and stay in shelter when the thermometer falls below $60^{\circ} \mathrm{F}$. On the other hand, they can labour in the sun with head and body exposed for a long time. They drink seldom and go a long time without food. The voice varies a good deal. On the south end of the island there is a trill in the speech which is pleasant to the ear. On the east coast it is hoarse and guttural. On the north end and down the west coast the voice has a shrill metallic ring. By these characteristics one can tell the district from which a person comes. Excretory functions, so far as known, are normal, except that the Tannese perspire freely.

Odour.-There is, I think, a distinct Tannese odour. I could tell a group of Amityumese or Aniwarus from a group of Tannese by their odour. Single individuals cannot be distinguished in this way. To do so you need to get about twenty natives together, fresh from their village, who have walked a few miles on a warm day. Their odour depends upon a number of things, such as the food they eat, the smoke of the wood they burn, the material they use for clothing, the animals they keep, and the character of the soil on which they live. This odour is stronger in inland people than shore people, as the former bathe less frequently. The odour attaches more to women than men, due probably to the skirts they wear. If a dozen of these women pass through the room of a European house the odour will remain in the room for about twenty-four hours. 1 am not sure if natives recognise these odours; very likely they do.

Physical powers. - I have kept no record of weights lifted or carried, or the time taken to travel a distance. But as one brought up to manual labour and able to endure hard work, I have tested them alongside of myself. They could beat me at lifting and carrying a dead weight, such as shifting a stone, the end of a boat, or a box. A number of them will carry a very heavy case quite a long distance over a had road. In walking, natives could do the journey easier and quicker than I could-they carrying a burden, I none. In steady pick and shovel work natives could do more than I could the first day. We were about equal the second day. On the third day they fell far behind me, and were unwilling to work.

The Senses.-Sight:-The natives can see a boat or canoe out at sea which I could see only with a glass, and they could tell a man from a woman walking along the shore nearly four miles away. Hearing :-I have never observed any particular acuteness in hearing, indeed I am inclined to think that they are behind Europeans in this respect. Smell :-I have not seen any evidence of particularly acute smell. In this I do not think they equal an average European. They dislike the smell of a foul ulcer, a dead animal, and bad meat. Over such smells they will spit and exclaim for a long time. Yet they will eat stinking human flesh and fermented bread fruit. The latter is to Europeans a most horrible smell. They are pleased with the odour of roast meat, savoury soup, 
of a native oven just opened, the scented croton and European scents. Taste :The native taste is quite different from the European. To us their food is at first quite unpalatable. Their foods are generally taken without salt. Pepper and ginger they dislike, so also anything sour. They do not take readily to sour fruits, but they take quickly to anything sweet, and soon cultivate a taste for salt and pepper in their food. Touch:-There is no evidence of acute touch.

Attitudes and movements.-Sleep: Women lie often without anything under the head. Boys and men hang the head over a wooden pillow or support about as thick as the forefinger, raised about 6 inches from the ground. The neck at the junction of the occiput rests on this, and the constant use of such a head-rest produces a corn across the back of the neck.

Men usually stand to micturate, women and children (including small boys) sit down.

Women sit up in being delivered and attend to themselves throughout.

The body has a graceful poise in walking, the toes are turned inwards and the foot planted firmly, but in running the toes are about straight. The gait is energetic and head carried back. Women when walking without burdens put one shoulder forward and then the other while the hand hangs free with the palm turned backwards.

They move objects by pushing and pulling, but the first effort is generally a push. Women carry a burden fastened on the back with rope brought from the bundle, across the chest, first one way then the other, like a man's braces. Two men carry yams, pigs, and cocoa-nuts between them on a pole resting on their shoulders. One man carries a load, such as cocoa-nuts, on each end of a stick on his shoulder, so that part of the weight is behind and part in front. It is considered undignified for a male to carry a burden like a woman; but women may carry a pig between them on a pole like the men.

Most natives can climb trees, but a few are giddy when they do so. In climbing a cocoa-nut tree the hands are put round the further side of the trunk, the feet are planted crosswise on the side of the trunk next the climber, and the body is kept clear of the tree trunk. Natives will climb an almost perpendicular cocoa-nut tree 60 feet high, with perfect ease.

Tannese have considerable power over all the muscles of the face and scalp, but I have not noticed whether they have the power of moving the ear. They are alle to acquire the power of shutting one eye.

To indicate direction behind or at the side, a person points with his thumb, keeping the other fingers shut; the direction of an object in front is indicated with the open hand, the palm being kept in the direction intended to be shown. Beckoning with the hand is the very opposite of ours.

The sleight of hand tricks practiced are of the simplest kind, such as our use of the thumb to make a child believe that its nose is taken off.

Any object like a knife can be lifted from the ground with the foot and is even carried some distance by means of the toes hefore being transferred to the 
hand. There is no indication of the great-toc being opposable like the thumb, but it stands clear of the next toe. The joints of the toes are bendable at will.

Heredity.-There is an entire-absence of strict caste. I never saw a really distinct case of albinism or erythrism. I have noted that families accustomed to live in malarious places suffer less than visitors to such places from malarial fever. I am not inclined to think that S. S. Islanders swim readily through any hereditary influence; every child has to be taught to swim, but they are so accustomed to sea bathing from infancy that a child never knows fear of water, and can swim as soon as it can walk. While a little kitten a few hours old will keep its head above water, an infart (native) would drown at once. Tannese, and all natives, have a marvellous power of recovering from injury to the body. Excessive power of imagination is universal in the way of hearing sounds attributed to spirits-such as the tramp of the feet of dancers.

Crosses.-I have had no Tannese cross breeds under observation, but there is little doubt that the Tannese are no longer pure bred. At present, whatever may be the cause, the birth rate is very low. The best looking couples are childless, and families are generally small. It seems to be the feeblest and most unhealthy women that have most children. Yet there must have been a time when the mothers were most prolific.

Physiognomy.-Astonishment is expressed by an exclamation or series of them-Awe! Yakame! Kositen! The mouth is opened, the lips drawn back from the teeth, the tip of the tongue kept behind the lower front teeth and the body of the tongue forced against the upper teeth, the eyes are opened wide and the brows lifted, the arms are flung about as if the person wished to throw them away. A blush passes all over the face in shame. In indignation a man scolds and turus and walks defiantly away. In thinking deeply the whole skin of the fice is drawn towards the eyes. In despair there is a relaxing of all the muscles of the face. In good spirits the face is clear and childlike. Contempt is expressed by shooting out the lips and forcing the spittle through teeth and lips, and by putting out the tongue and rolling it about with a noise like children make with the tongue, also by wild unnatural loud mocking laughter. Disgust is expressed by contortions of the face and spitting. Fear is shown by exclamation (Awe :), shrinking back, blanching of the face and the straightening of the curliest hair. Laughter may be carried to the extreme of tears. Inability to do a thing is expressed by lifting one or both shoulders up about the neck. Children are extremely self-willed and pout much as white children do. Guilt is recognised by the individual shunning the person wronged and by apparent unconcern when taxed with wrong-iloing. Jealousy can be detected by the look and manner. Assent is expressed by a rertical nod of the head, or lifting the eyebroxis. Negation is expressed hy the lateral shake of the head, firm pursing of the lips, lifting of the hand aud waving it palm outwards toward the person speaking.

P.ycllolog?y-DTannese are capable to a small extent only, of an abstract idea. The laculty of mental attention is easily wearied although patience is an out- 
standing trait. The memory is good for experimental incidents. I do not think a native could draw a map of an island. A man has no idea of his own age, and the only way he can give an idea of it is by speaking of some marked person who lived when he was a boy. Most natives are polyglots and speak more than one dialect. Some natives show no aptitude in learning a foreign language, but as a rule 'Tannese learn foreign languages readily, though they do not always pick up the intricacies. Perseverance is a markerl feature in native occupations, but very little gift is displayed in acquiring a foreign habit. A man will fish day after day though he get nothing. Plantations are made in spite of successive failures of the crop. They are deft carvers in their own rude fashion. Curiosity is not. excited if the new object be very complicated. Yet a chimney and weather vane has created immense curiosity. Their own sacred stones excite a keen clesire to see them, while the sight of them fills them with horror. Curiosity is limited by the power of understanding an object, and its use. A barometer is a useful thingit tells what sort of weather is coming. A raingange is a foolish thing-what does one want to count the rain for, when there is so much of it? On the whole, curiosity is strong. It can hardly be said that there is any sequence of ideas properly so called. If a person were passing along a path and some creature (say a snake) fell on lim out of a tree, and next day, or the week after, he heard of the death of a son in Queensland, he would connect the two. A turtle came ashore one night and laid a nestful of eggs. It was captured in the act. Such a thing had never taken place in the memory of the people. The conclusion was that Christianity was the cause of the turtle coming ashore to lay its eggs, and the right thing to do was to offer the turtle to the missionary who had brought the worship of Jehovah. I have, however, had evidence of natives having a true sequence of ideas, but of a simple character, and born of experience. I cannot think of a better instance just now than shaping the end of a canoe so as to ride over the water or part it without shipping the sea; also the custom of keeping the outrigger to the windward in sailing. I have seen more abstract instances, but they were not separable from education and European influence. The native's mind is so constituted that there is to him no absurdity in believing what are, to us, two absolutely contradictory things. A native can think of both as true. A large number of things retard progress in acquiring habits of civilised life. Their own manner of life is good enough in their idea. Native customs die hard, and are connected with their religious beliefs. While there is a measure of incapacity, there is enough capacity to easily make a beginning in the acquisition of civiliser halits. Civilisation of natives in situ, though slower, is unquestionably sounder than the civilisation of natives in a civilised country. Tannese who have been in Queensland for fifteen or twenty years return at once to savage ways. Civilised customs introduced in situ are, however, modified by native surroundings, but the effect is radical. Civilisation got abroad is little more than a veneer. We liave never liad a casc of a child taken from Tanna to be trained and educated as a civilised child, but some light on the question may be gleaned from the fact that boys and 
girls taken home by missionaries, have turned out very unsatisfactory. They have hecome conceited, lazy, and put on "airs," and in some cases have gone back to savage life and heathenism. Without much hesitation, as the result of observation, I venture the opinion that there is a limit to the native capacity for education, and that capacity is a low one. It would be impossible to take an average native boy, as one would take a boy from our back streets, and give him an university education. Probably the standard of a State school Fourth Form would be the highest education possible for a native boy. Indeed, it is questionable if he could be educated to pass in all subjects in the Fourth Form. To attempt more would almost certainly result in some form of insanity or death. In making implements and tools the Tannese copy exactly their ancestors. No improvements are made on these. Tannese take a long time to make up their minds, and are easily talked over to some other resolve. As a whole they are not voluble of speech, and repeat themselves in speaking. The same explanation will be given over and over again to the same persons. Tannese are capable of deep emotion, but they have marvellous control of themselves. A person will be furiously angry and never show it. If it suits him to make a display of his anger, he can do so in a most terrifying manner. They are subject to illusions and make a good deal of clear dreams. I have not heard of or seen a Tannese in a trance. Illiots are not uncommon, but insanity is rare. Suicide is not infrequent-chiefly through grief or hopeless and painful illness.

\section{Explanation of Plate XI.}

Group of three Tanna men ; from a photograph taken in Tanna, in 1893, by the Rev. J. H. Lowrie, Presbyterian Mission.

MAY 24TII, 1898.

F. W. Rudler, Esq., F.G.S., President, in the Chair.

The Minutes of the last Meeting were read and signed.

The election of J. W. Sirald, Esq., of Jaffina, Ceylon, as a Fellow of the Institute was announced.

Professur E. B. TyLon, D.C.I., F.R.S., read the three following papers :-

1. "A Description of the Totem-Post from British Columbia, now erected in the grounds of Fox Warren, near Weybridge."

2. "On two Haida House-Posts with Totem Carvings in the Pitt-Rivers Museum, Oxford."

3. "Remarks on Totemism, with especial reference to some modern theories respecting it."

The discussion was carried on by Mr. ANdrew Lang, Mr. H. Balfour, and Mr. E. CLODD.

A hearty vote of thanks was passed to Professor Tylor on the motion of the President, who also thanked Dr. Garson for exhibiting some illustrative lantern slides. 


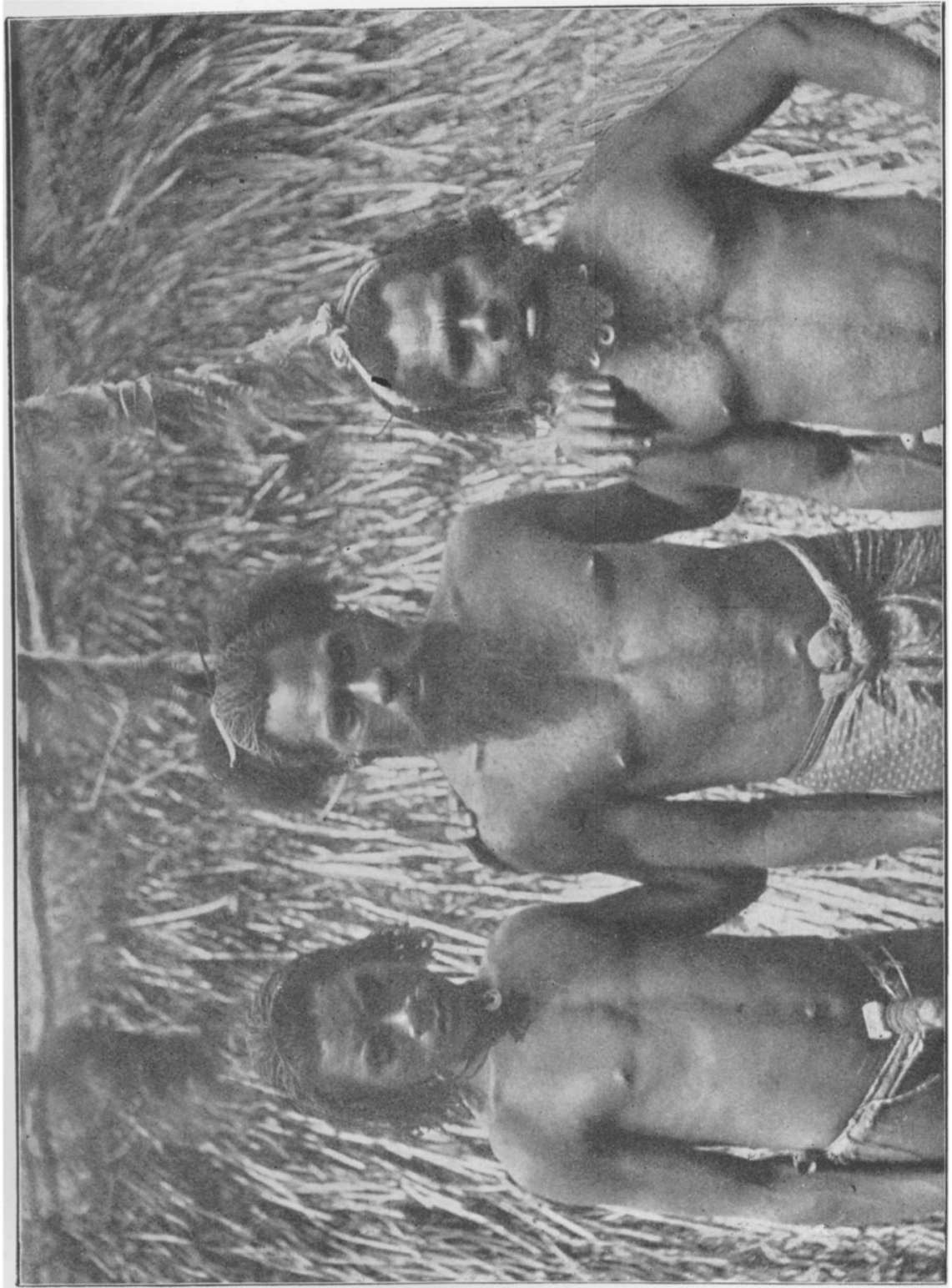

